\title{
Fuel Cell-Based Cogeneration System Covering Data Centers' Energy Needs
}

\author{
Giuseppe Leo Guizzi ${ }^{\mathrm{a}}$, Michele Manno ${ }^{\mathrm{a}, *}$ \\ ${ }^{a}$ Facoltà di Ingegneria, Università degli studi di Roma Tor Vergata, Italy
}

\begin{abstract}
The Information and Communication Technology industry has gone in the recent years through a dramatic expansion, driven by many new online (local and remote) applications and services. Such growth has obviously triggered an equally remarkable growth in energy consumption by data centers, which require huge amounts of power not only for IT devices, but also for power distribution units and for air-conditioning systems needed to cool the IT equipment.
\end{abstract}

This paper is dedicated to the economic and energy performance assessment of a cogeneration system based on a natural gas membrane steam reformer producing a pure hydrogen flow for electric power generation in a polymer electrolyte membrane fuel cell. Heat is recovered from both the reforming unit and the fuel cell in order to supply the needs of an office building located near the data center. In this case, the cooling energy needs of the data center are covered by means of a vapor-compression chiller equipped with a free-cooling unit.

Since the fuel cell's output is direct current rather than alternate current, the possibility of further improving data centers' energy efficiency adopting DCpowered data center equipment is also discussed.

Keywords: Data center, Cogeneration, Energy efficiency, District heating, Hydrogen, PEMFC, Membrane reformer

\footnotetext{
* Corresponding author

Email addresses: guizzi@ing.uniroma2.it (Giuseppe Leo Guizzi), michele.manno@uniroma2.it (Michele Manno)
} 


\section{Introduction}

In recent years, the rapid growth of the Information and Communication Technology (ICT or, more simply, IT) industry has brought about a strong worldwide expansion of energy use by data centers, which lie at the core of the industry. Recently, a study [1] has estimated that electric energy consumption by data centers in the world has more than doubled in the period from 2000 to 2005 ; furthermore, it showed that in 2005 it represented $1 \%$ of world total electric energy consumption. This growth is estimated to continue on this exponential trend at least in the near future [2].

More specifically, Fig. 1 shows that energy consumption for cooling purposes, combined with energy losses due to the power distribution units (including UPS), is indeed remarkable if compared to the energy really absorbed by the IT equipment in the data center: with current technologies, the ratio between IT equipment power and total facility power can be on average estimated as 0.5. This ratio has been designated as DCiE (Data Center Infrastructure Efficiency) by The Green Grid, an organization grouping several major IT companies and promoting efficiency in IT industry; DCiE, along with its reciprocal PUE (Power Usage Effectiveness), are recommended by this organization as useful metrics in order to assess data center efficiency [3].

The value of 0.5 is indeed the figure used in [1] in constructing its estimate, represented in Fig. 1, and also found valid in [4], but the situation can be even worse in particular occasions: for example, [5] found a DCiE of 0.29 for the relatively small data center analyzed, while in [6] values of 0.5 and 0.26 for two different data centers located in Singapore are reported, and, finally, in [7] the energy performance of 22 data centers is reviewed, with DCiE values ranging from 0.33 to 0.75 , with an average value of 0.57 .

In order to further emphasize the importance and relevance of the subject, it is worth mentioning that US Congress, through Public Law 109-431, requested the Environmental Protection Agency to "analyze the rapid growth and the energy consumption of computer Data Centers", as well as to evaluate possi- 
ble standards for increasing energy efficiency in the industry. The report [8] clearly points out the following technologies and solutions for energy-efficiency improvement: using high-efficiency power distribution and UPS units; using state-of-the-art cooling equipment; monitoring power in real time; using combined heat and power, with on-site generation with the electric grid as backup.

Currently, data centers rely on the electric grid for energy supply, with conventional HVAC systems providing the cooling power required, which thus produce a further consumption of electric energy, still drawn from the grid (power consumption for cooling purposes can be $25 \%$ or more of the total data center power [2]). A UPS unit is always present in order to ensure the necessary level of security and protection for the electronic devices, both towards dangerous effects of electric disturbances (transient over-voltages or drops in voltage, voltage peaks, frequency variations) and towards grid interruptions (micro-interruptions or black-outs). Finally, an emergency electric generator (usually based on a diesel internal combustion engine) can be optionally included, with the only task of guaranteeing continuity of operation during prolonged grid interruptions.

In a previous paper [9] the authors analyzed energy and cost savings that could be achieved by means of a CCHP system based on an internal combustion engine that supplies the electric power to the data center facility, coupled to a single-stage absorption chiller driven by the engine's discharge heat in order to meet the cooling power requirements.

In this paper another distributed generation plant, based on the integration of a natural gas membrane reformer and of a polymer electrolyte fuel cell, is considered as an alternative to the conventional thermal engine analyzed in the previous paper. A vapor-compression chiller equipped with free-cooling units is used to meet the cooling load of the data center rather than an absorption chiller, due to the particularly high electric efficiencies that can be achieved in this case, and also because a significant part of heat is recovered in the CHP plant at temperatures generally too low to be suitable for operating absorption chillers (high-temperature PEM fuel cells, which could solve this problem and thus possibly provide even more energy savings, are not taken into consideration 
here).

Furthermore, in order to improve the data center's own efficiency, a power distribution system based on high voltage direct current is considered instead of the conventional one based on alternating current: recent studies $[10,11]$ have demonstrated the potential of direct current systems for reducing overall power consumption in data centers thanks to the elimination of several AC/DC conversion steps. The direct current layout is also particularly suited to be integrated with the CHP system, which delivers direct current through its PEM fuel cell, as well as with renewable sources such as photovoltaic modules.

\section{Conventional data center energy scenario}

\subsection{Data center energy requirements}

The electric load generated in the conventional scenario has been evaluated with reference to available literature data $[8,12]$ and represented in Table 1. In this table, average PUE values (equipment power to IT power ratio) for the different equipments of a data center are given, according to several scenarios taken into account in the EPA report.

In this paper data from the "improved operation" scenario have been considered, since in this case the overall PUE of 1.7 (corresponding to a DCiE of $0.59)$ is the closest to current values found in the literature $[1,2,4-7]$.

Therefore, according to Table 1 and taking into account an average IT power consumption $P_{e l, I T}=100 \mathrm{~kW}, 27 \mathrm{~kW}$ are required by the UPS, the transformer and the lighting equipment; $13 \mathrm{~kW}$ are needed to operate the HVAC auxiliaries; finally, $30 \mathrm{~kW}$ are required by the chiller unit. The total load is therefore $P_{e l, t o t}=170 \mathrm{~kW}$.

These data can also be used to determine the actual cooling load generated by the data center: with the assumption that all power absorbed by the IT equipment and lighting is ultimately transformed into heat, and that the power losses by UPS and transformer are also turned into waste heat, the cooling load is therefore $P_{f r}=P_{\text {el,base }}=127 \mathrm{~kW}$. 
In order to evaluate the overall energy consumption of the data center, two further assumptions are made:

- the load is almost constant throughout both the day and the year (data center's equivalent operating hours $h_{e q, I T}=8760 \mathrm{~h}$ ). This can indeed be the case for data centers housing critical IT equipment (servers, storage and network systems) that need to be operating on a continuous basis;

- the cooling load is not affected by ambient temperature fluctuations, so that the cooling power required is also almost constant throughout the day and the year. This assumption is correct for many data centers that indeed have minimal surface exposure to the outside and are confined within an air-conditioned facility $[6,13]$, but obviously should be checked case by case.

The electrical energy annually required in this scenario is therefore:

$$
E_{e l}=P_{e l, t o t} h_{e q, I T}
$$

Annual operating costs related to the electrical energy consumption are calculated by means of the following equation (current electric energy cost in Italy can be estimated as $\left.c_{E E}=16 \mathrm{c} € / \mathrm{kWh}\right)$ :

$$
C=c_{E E} E_{e l}
$$

Since this energy scenario is to be compared to a cogeneration one, the average grid efficiency used to calculate the primary energy consumption is taken from the Italian Energy Authority deliberations regulating cogeneration facilities. The resulting value for a power plant with rated power lower than $1 \mathrm{MW}$ fueled by natural gas is $\eta_{e l, r e f}=38.28 \%$, taking an average efficiency $\eta_{e l, \text { grid }}=40.0 \%$ and transport losses over the grid for a medium-voltage grid connection accounting for a $4.3 \%$ penalty (AEEG deliberations n. 42/2002, updated by n. 296/2005 and n. 307/2007). Thus:

$$
E=E_{e l} / \eta_{e l, r e f}
$$


Finally, annual $\mathrm{CO}_{2}$ emissions related to this scenario are calculated on the basis of specific emissions by thermoelectric power plants $\left(e_{\mathrm{CO}_{2}, E E}=496 \mathrm{~g} / \mathrm{kWh}\right)$ indicated by the Italian utility ENEL [14]:

$$
m_{\mathrm{CO}_{2}}=e_{\mathrm{CO}_{2}, E E} E_{e l}
$$

\subsection{Thermal load definition}

In this case study, beside the data center electric and cooling loads discussed in the previous section, the heating load of an office building housing the data center is added to the energy scenario. The heating load is determined, according to Italian regulations, as follows:

$$
E_{t h}=\left(\varepsilon_{w h}+\varepsilon_{t h} \delta\right) V
$$

where $\varepsilon_{w h}$ is the volumetric thermal energy required for water heating, $\varepsilon_{t h}$ is the volumetric thermal energy required for proper heating purposes for each heating degree day $(\delta)$, and $V$ is the office building volume. The heating degree day index is defined as the sum of the positive differences between the reference temperature of $20^{\circ} \mathrm{C}$ and the daily average ambient temperature over a given reference heating period. The values of annual heating degree days for any Italian city is regulated by DPR n. 412/1993; for the three locations considered in this paper these values are: 2404 for Milan, 1415 for Rome, 751 for Palermo. In order to evaluate the monthly distribution of the thermal load, the number of heating degree days is then distributed over the year according to the definition of heating degree days given above, taking into account the average ambient temperature for these cities, measured at the meteorological stations located at Linate (Milan), Ciampino (Rome) and Punta Raisi (Palermo) airports.

The assumptions made in this case study are:

- heat loads in Eq. (5): $\varepsilon_{t h}=10.83 \mathrm{Wh} \mathrm{m}^{-3} \mathrm{~K}^{-1}, \varepsilon_{w h}=1.0 \mathrm{kWh} \mathrm{m}^{-3}$;

- office building volume: $15000 \mathrm{~m}^{3}$.

The resulting annual heat load is thus 405.5 MWh for Milan, 244.9 MWh for Rome and 137.0 MWh for Palermo. In order to calculate the primary energy 
consumption related to these thermal loads, it is necessary to introduce the thermal efficiency of conventional boilers $\eta_{t h, c i v}=0.80$ (this value is again indicated by the Italian Energy Authority as reference for non-industrial appliances), so that total primary energy consumption is:

$$
E=E_{e l} / \eta_{e l, r e f}+E_{t h} / \eta_{t h, c i v}
$$

Natural gas ${ }^{1}$ consumption is calculated as follows, taking into account a lower heating value $\Delta h_{L H V, \mathrm{NG}}=875.2 \mathrm{~kJ} \mathrm{~mol}^{-1}=39.05 \mathrm{MJ} / \mathrm{m}_{\mathrm{n}}^{3}$ :

$$
V_{n, \mathrm{NG}}=\frac{E_{t h}}{\eta_{t h, c i v} \Delta h_{L H V, \mathrm{NG}}}
$$

Total operating costs and $\mathrm{CO}_{2}$ emissions are thus evaluated according to the following equations:

$$
\begin{gathered}
C=c_{E E} E_{e l}+c_{N G} V_{n, N G} \\
m_{\mathrm{CO}_{2}}=e_{\mathrm{CO}_{2}, E E} E_{e l}+e_{\mathrm{CO}_{2}, N G} V_{n, N G}
\end{gathered}
$$

with natural gas cost estimated as $c_{N G}=46 \mathrm{c} € / \mathrm{m}_{\mathrm{n}}^{3}$ with reference to the Italian market, and specific $\mathrm{CO}_{2}$ emissions $e_{\mathrm{CO}_{2}, \mathrm{NG}}=2.725 \rho_{n, \mathrm{NG}}=2.212 \mathrm{~kg} / \mathrm{m}_{\mathrm{n}}^{3}$.

\section{Proposed data center energy scenario}

\subsection{Direct current power delivery system}

The architecture of a typical data center power delivery system, shown on top of Fig. 2, is currently based on AC power, distributed to the facility at 480 V. An uninterruptible power supply (UPS) is used to isolate equipment from power interruptions or other disturbances and to provide emergency backup energy storage usually by means of batteries: therefore inside the UPS, AC power is first converted to $\mathrm{DC}$ which is then converted back to $\mathrm{AC}$ for the facility distribution grid and routed to power distribution units (PDUs) for distribution

\footnotetext{
${ }^{1}$ Natural gas composition is assumed as follows: $\mathrm{CH}_{4} 89.0 \% ; \mathrm{C}_{2} \mathrm{H}_{6} 6.6 \% ; \mathrm{C}_{3} \mathrm{H}_{8} 2.1 \%$; $\mathrm{C}_{4} \mathrm{H}_{10} 0.9 \% ; \mathrm{CO}_{2} 0.6 \% ; \mathrm{N}_{2} 0.8 \%$. The resulting molecular weight and density at normal conditions are thus: $M_{\mathrm{NG}}=18.20 \mathrm{~kg} \mathrm{kmol}^{-1}$ and $\rho_{n, \mathrm{NG}}=0.812 \mathrm{~kg} / \mathrm{m}_{\mathrm{n}}^{3}$.
} 
to equipment in racks [11]. Inside the servers and other IT equipment such as storage or networking units, power supply units (PSUs) convert AC (at $120 \mathrm{~V}$ $\mathrm{AC})$ to $12 \mathrm{~V}$ DC voltage as needed by the digital equipments. Further conversions may be required and performed by dedicated voltage regulator modules (VRM) inside the electronic device.

A DC power distribution architecture (Fig. 2 bottom) can be used to avoid several electric power conversion stages, thus eliminating the associated power losses. Indeed, direct current data centers have been set up and tested in order to assess the energy efficiency gains that could be achieved [10, 11], with rather good results: an end user could obtain an improvement of 4-6\% efficiency points over well designed efficient AC systems currently available [10]. Based on these estimates, since in the reference "improved operation" scenario of Table 1 the power losses of UPS and PDU combined are $0.25 \mathrm{~W}$ for $1 \mathrm{~W}$ of IT power, in the alternative energy scenario these losses have been reduced to $0.15 \mathrm{~W}$ for 1 $\mathrm{W}$ of IT power. Furthermore, the reduction of power losses in the conversion stages is doubly beneficial because it also reduces the cooling load on the HVAC system, so that base electric power and cooling load have been reduced to $P_{f r}=$ $P_{\text {el,base }}=117 \mathrm{~kW}$.

\subsection{Membrane reformer}

The steam reforming unit must accomplish the conversion of the fuel input to hydrogen, through the steam reforming reactions:

$$
\begin{gathered}
\mathrm{CH}_{4}+\mathrm{H}_{2} \mathrm{O} \rightleftarrows \mathrm{CO}+3 \mathrm{H}_{2} \\
\mathrm{C}_{2} \mathrm{H}_{6}+2 \mathrm{H}_{2} \mathrm{O} \rightleftarrows 2 \mathrm{CO}+5 \mathrm{H}_{2} \\
\mathrm{C}_{3} \mathrm{H}_{8}+3 \mathrm{H}_{2} \mathrm{O} \rightleftarrows 3 \mathrm{CO}+7 \mathrm{H}_{2} \\
\mathrm{C}_{4} \mathrm{H}_{10}+4 \mathrm{H}_{2} \mathrm{O} \rightleftarrows 4 \mathrm{CO}+9 \mathrm{H}_{2}
\end{gathered}
$$

and the water-gas shift reaction:

$$
\mathrm{CO}+\mathrm{H}_{2} \mathrm{O} \rightleftarrows \mathrm{CO}_{2}+\mathrm{H}_{2}
$$


In a conventional fuel processor, the steam reforming unit is composed of several reactors. The first one is the main reformer, where high temperatures $\left(800 \div 850{ }^{\circ} \mathrm{C}\right)$ are maintained in order to shift the endothermic $\left(\Delta_{r} H^{0}=\right.$ $206.17 \mathrm{~kJ} \mathrm{~mol}^{-1}$ for methane steam reforming) steam reforming reactions to the right, thus increasing hydrogen's yield. The reformate stream is then fed into two water-gas shift reactors maintained at lower temperature $\left(\sim 400{ }^{\circ} \mathrm{C}\right.$ and $\left.\sim 200^{\circ} \mathrm{C}\right)$ where the exothermic $\left(\Delta_{r} H^{0}=-41.17 \mathrm{~kJ} \mathrm{~mol}^{-1}\right)$ water-gas shift reaction (14) is catalytically promoted in order to increase hydrogen production and to remove CO (poisonous for the PEM fuel cell) from the stream. Finally, the last component is a low-temperature $\left(\sim 100^{\circ} \mathrm{C}\right)$ PROX (Preferential Oxidation) unit, where the remaining $\mathrm{CO}$ is catalytically burned with oxygen in order to reduce $\mathrm{CO}$ concentration in the reformate stream at values acceptable for the operation of a PEM fuel cell.

A membrane reactor differs from a conventional one under several points of view. The fuel input is fed, together with water vapor, to the reformer (Fig. 3 ), which usually consists of a first section where natural gas and water react at high temperature according to equilibrium reactions (10)-(14), immediately followed (inside the same component) by a section where a hydrogen-selective membrane divide the feed area, where the reformate stream flows on a catalyst bed promoting the steam reforming reaction, from a permeate area, where hydrogen permeated across the membrane is collected. The heat input necessary to sustain the reactions is supplied by hot gases, resulting from the combustion of the "retentate", flowing outside the reactor (Fig. 3), which still contains significant amounts of hydrogen, methane and carbon monoxide (Table 3).

The main advantage of this configuration is that reactions (10)-(14) are shifted to the right mainly by the subtraction of one product $\left(\mathrm{H}_{2}\right)$ from the stream, so that the reformer temperature can be significantly lower than in conventional reformers (high temperatures are however favorable, being the overall process endothermic), with obvious benefits in terms of process efficiency [15$17]$.

Many different membrane types have been subjected to extensive research 
and experimentation, but in this paper palladium-based dense membranes are considered for their good compromise between permeance and selectivity [15].

Hydrogen permeation through a Pd-based membrane involves seven sequential steps [17], but the diffusion of atoms through the bulk membrane is usually the rate determining step [17], so that hydrogen permeation through the membrane can be expressed by Richardson's law [15]:

$$
J=\frac{k}{t}\left(p_{\mathrm{H}_{2}, f}^{0.5}-p_{\mathrm{H}_{2}, p}^{0.5}\right)
$$

where $k$ is the permeability of the membrane, $t$ its thickness, $p_{\mathrm{H}_{2}, f}$ and $p_{\mathrm{H}_{2}, p}$ hydrogen's partial pressures on the feed side and on the permeate side, respectively. Membrane's permeability depends on temperature according to an Arrhenius expression:

$$
k=k_{0} \exp \left(\frac{-E_{a}}{R T}\right)
$$

A lumped-parameter model has been set up in order to evaluate the membrane area required to obtain a specified hydrogen recovery factor, which is defined as the ratio of hydrogen permeated through the membrane to the amount of hydrogen that could be theoretically obtained if reactions (10)-(14) would proceed to completion. For natural gas as the fuel input, reactions (10)-(14) combined yield:

$$
\gamma=\frac{\dot{n}_{\mathrm{H}_{2}, p, \text { out }}}{\left(4 x_{\mathrm{CH}_{4}}+7 x_{\mathrm{C}_{2} \mathrm{H}_{6}}+10 x_{\mathrm{C}_{3} \mathrm{H}_{8}}+13 x_{\mathrm{C}_{4} \mathrm{H}_{10}}+x_{\mathrm{CO}}+x_{\mathrm{H}_{2}}\right) \dot{n}_{\mathrm{NG}, \text { in }}}
$$

The reactor has been considered isothermal and subdivided in a sequence of $N_{c v}$ control volumes; inside each control volume the stream coming from the previous one reacts according to reactions (10)-(14) reaching equilibrium conditions. For the $i^{\text {th }}$ control volume, hydrogen flux $J^{i}$ through the membrane is then evaluated according to hydrogen's partial pressure by using Richardson's law expressed by Eq. (15), and the membrane area is finally calculated taking into account a constant amount of hydrogen permeated in each control volume: $A_{m}^{i}=\dot{n}_{\mathrm{H}_{2}, p, \text { out }} /\left(N_{c v} J^{i}\right)$. The hydrogen permeated is then subtracted from the stream on the feed side of the reactor, which is fed to the following control volume, so that $\dot{n}_{\mathrm{H}_{2}, f}^{i+1}=\dot{n}_{\mathrm{H}_{2}, f}^{i}-J^{i} A_{m}^{i}$. 
The temperature in the steam reformer unit (Table 2) has been taken as high as possible, the upper limit being close to the maximum temperature allowable by the $\mathrm{Pd}$ membrane $\left(\sim 650{ }^{\circ} \mathrm{C}[15]\right)$, because high temperatures shift the equilibrium reactions to the right, thus increasing hydrogen's partial pressure on the feed side and consequently hydrogen's flux $J$, resulting in a lower membrane area required for a given hydrogen recovery factor. Increasing feed total pressure is equally beneficial for reducing membrane area, but membrane's mechanical strength must be taken into account on this respect (furthermore, it also increases natural gas' compressor power consumption). Pressure on the permeate side is determined by the fuel cell's operating conditions. In order to increase hydrogen's permeation across the membrane, a sweep stream on the permeate side could have been used so as to decrease hydrogen's partial pressure, but the resulting hydrogen's dilution would have been detrimental for the fuel cell's performance, as shown by Eq. (20).

Finally, a most important parameter for the steam reforming process is the "steam-to-carbon" ratio, defined as the ratio between the molar flows of water vapor and natural gas into the reformer:

$$
\sigma=\frac{\dot{n}_{\mathrm{H}_{2} \mathrm{O}, i n}}{\dot{n}_{\mathrm{NG}, i n}}
$$

For a conventional steam reforming unit, increasing values of $\sigma$ yield higher hydrogen conversion factors [18], because equilibrium reactions (10)-(14) are shifted to the right, at the cost of a larger thermal input required for producing the necessary amount of water vapor.

In a membrane reforming unit, instead, increasing the steam-to-carbon ratio has two opposed effects on the membrane area required to achieve a given value of hydrogen recovery factor: on the one hand, higher values of $\sigma$ are beneficial for the same reason detailed above for conventional reforming units (equilibrium reactions are shifted to the right); on the other hand, though, hydrogen's partial pressure on the feed side $p_{\mathrm{H}_{2}, f}=\left(\dot{n}_{\mathrm{H}_{2}, f} / \dot{n}_{f}\right) p$ decreases with $\sigma$, since both $\dot{n}_{\mathrm{H}_{2}, f}$ and $\dot{n}_{f}$ increase with $\sigma$, but the first less rapidly than the second, so that, taking into account Eq. (15), the permeation through the membrane decreases with 
$\sigma$. In this situation an optimum value of steam-to-carbon ratio may be found, and indeed this is what is shown in Fig. 4, which illustrates the influence of the steam-to-carbon ratio on total membrane area calculated with the model described above, with reference to a unit input flow of natural gas (operating conditions are summarized in Table 2): the minimum is found for $\sigma \cong 3.7$, which is thus taken as a further operating condition in the simulations concerning the whole data center energy scenario discussed in the following sections.

\subsection{PEM fuel cell}

In this work a PEM fuel cell is considered for its high power density, fast start-up capability and relatively low-cost materials [15].

Cell voltage and efficiency values are taken from a previous work on a small mobile system [19] including a PEM fuel cell, which is here considered as a reasonable (and conservative) reference system for the stationary fuel cell required by the proposed CHP plant. The polarization curve (cell voltage vs current density) can be expressed in the following analytical form (empirical coefficients are listed in Table 4):

$$
V_{\text {cell }}=E^{r e v}-\frac{R T}{\alpha n_{e} F} \log \frac{i}{i_{0}}-r i-m \exp (n i)
$$

where $E^{r e v}$ is the reversible cell potential:

$$
E^{r e v}=E^{0}+\frac{R T}{n_{e} F} \log \left(\frac{a_{\mathrm{H}_{2}} a_{\mathrm{O}_{2}}^{1 / 2}}{a_{\mathrm{H}_{2} \mathrm{O}}}\right)
$$

The theoretical cell voltage at standard temperature and pressure $E^{0}$ is related to the change in molar Gibbs' free energy of formation $\Delta_{f} g^{0}$ :

$$
E^{0}=\frac{-\Delta_{f} g^{0}}{n_{e} F}
$$

For the reaction $\mathrm{H}_{2}+\mathrm{O}_{2} \rightarrow \mathrm{H}_{2} \mathrm{O}_{g}, \Delta_{f} g^{0}=-228.6 \mathrm{~kJ} \mathrm{~mol}^{-1}$ so that $E^{0}=$ $1.1848 \mathrm{~V}$; if air is used as oxidant $\left(x_{\mathrm{O}_{2}}=0.21\right)$, the reversible cell potential is thus $E=1.1733 \mathrm{~V}$ at the fuel cell operating temperature of $70{ }^{\circ} \mathrm{C}$.

The cell efficiency is then evaluated with reference to the change in molar enthalpy of formation at standard temperature and pressure, which for the above 
mentioned reaction is $\Delta_{f} h^{0}=-241.8 \mathrm{~kJ} \mathrm{~mol}^{-1}$ if hydrogen's lower heating value is considered:

$$
\eta_{F C}=\frac{n_{e} F V_{c e l l}}{-\Delta_{f} h^{0}}
$$

The fuel cell in this plant layout can work in a dead-end configuration because of hydrogen's high purity resulting from the membrane separation process, so that the fuel utilization factor can be considered equal to 1, leaving aside very small quantities of hydrogen leaked to the environment due to the periodical purging of accumulated inerts [15].

\subsection{CHP plant data}

The fuel cell must be sized so as to supply, at rated conditions, a net power output $P_{e l, n e t}=170 \mathrm{~kW}$ : taking into account power losses related to $\mathrm{DC} / \mathrm{DC}$ converters, fuel cell's auxiliary units and natural gas and air compressors, calculated according to the data presented in Table 5, the necessary stack power output is $P_{\text {el,stack }}=188.4 \mathrm{~kW}$. If a current density $i=0.30 \mathrm{~A} \mathrm{~cm}^{-2}$ at rated operating conditions is chosen, rated cell voltage and efficiency are, respectively, $V_{\text {cell }}=0.746 \mathrm{~V}$ and $\eta_{F C}=0.595$. With $N_{s}=2$ stacks of $N_{c}=1000$ cells connected in parallel (a reasonable value for this power size [20]) the overall stack voltage at rated power would therefore be $V=746.0 \mathrm{~V}$, and consequently the total current would be $I=P_{e l, s t a c k} / V=252.7 \mathrm{~A}$. The resulting cell area is thus $A_{\text {cell }}=I /\left(N_{s} i\right)=421.2 \mathrm{~cm}^{2}$, a size that is acceptable for the stationary power plant here considered.

In order for the fuel cell to be able to supply the required power output, the hydrogen flow must be $\dot{n}_{\mathrm{H}_{2}, p, o u t}=P_{\text {el,stack }} /\left(-\Delta_{f} h^{0} \times \eta_{F C}\right)=1.31 \mathrm{mols}^{-1}$; therefore, taking into account the hydrogen recovery factor $\gamma$ given in Table 2, according to Eq. (17) the steam reforming unit must be supplied with a natural gas input flow $\dot{n}_{\mathrm{NG}, \text { in }}=0.463 \mathrm{mols}^{-1}$. The necessary membrane area thus results $A_{m}=29.09 \mathrm{~m}^{2}$, while the overall plant net electric efficiency at rated conditions is:

$$
\eta_{e l, C H P}=\frac{P_{e l, n e t}}{\dot{n}_{\mathrm{CNG}_{4}, \text { in }} \Delta h_{L H V, \mathrm{NG}}}=41.93 \%
$$


Thermal efficiency is shown to be particularly high thanks to the recovery of latent heat from both the exhaust streams (which is beneficial not only because it increases heat recovery but also because it makes the plant self-sufficient with respect to water supply ${ }^{2}$, a most important issue both from an environmental and an economic point of view [21]). At rated operating conditions heat recovery amounts to $P_{t h, C H P}=260.2 \mathrm{~kW}$ (low-temperature heat recovery particularly suitable for a heat distribution system using radiant panels), so the value of thermal efficiency is:

$$
\eta_{t h, C H P}=\frac{P_{t h, C H P}}{\dot{n}_{\mathrm{NG}, \text { in }} \Delta h_{L H V, \mathrm{NG}}}=64.16 \%
$$

As a concluding remark about the membrane reforming unit, the steam reforming efficiency obtained is $78.11 \%$ (based on the lower heating value), its definition being:

$$
\eta_{S R}=\frac{\dot{n}_{\mathrm{H}_{2}, p, \text { out }} \Delta h_{L H V, \mathrm{H}_{2}}}{\dot{n}_{\mathrm{NG}, \text { in }} \Delta h_{L H V, \mathrm{NG}}+P_{a u x, S R}}
$$

In this scenario, a state-of-the-art vapor compression chiller with free-cooling capabilities is used to meet the cooling load. The chiller taken as reference is the HITEMA ECFS 150 model, with rated power output 150 kW. Annual energy consumption is thus evaluated on a monthly basis, taking into account average COP and free-cooling power output of the chiller as functions of the ambient temperature (calculated according to data available on the manufacturer's web site):

$$
E=\sum_{i=1}^{12}\left[\frac{P_{e l, b a s e}+P_{e l, c h i l l e r}^{i}}{\eta_{e l, C H P}^{i}} h^{i}+\frac{\max \left(E_{t h}^{i}-E_{t h, r e c}^{i}, 0\right)}{\eta_{t h, c i v}}\right]
$$

with

$$
P_{\text {el,chiller }}^{i}=\frac{P_{f r}-P_{f r e e c o o l i n g}^{i}}{C O P^{i}}+P_{a u x}^{i}
$$

\footnotetext{
${ }^{2}$ Since the hydrogen produced is immediately consumed in the fuel cell within the overall system, the amount of water required to sustain the process is indeed recoverable from the exhaust streams, because at the end of the process all of the hydrogen contained in natural gas or produced from water in the steam reforming unit is oxidized to water, either in the combustor or in the fuel cell: therefore the exhaust streams contain all the water fed to the system and the water produced by oxidation of hydrogen contained in the fuel as well.
} 
being the chiller's monthly electric power consumption, and

$$
E_{t h, r e c}^{i}=\eta_{t h, C H P}^{i} \frac{P_{e l, b a s e}+P_{e l, c h i l l e r}^{i}}{\eta_{e l, C H P}^{i}}
$$

being the thermal energy that can be recovered by the CHP plant.

In the above equations, $h^{i}$ is the total number of hours for each month, while $P_{a u x}^{i}$ is the electric power required by chiller auxiliaries (pump, fans). The cooling and electric loads $\left(P_{f r}\right.$ and $\left.P_{e l, b a s e}\right)$ have been estimated as $117 \mathrm{~kW}$ in section 3.1. Net electric efficiency $\eta_{e l, C H P}^{i}$ may vary due to variations in the overall electric load, which in this analysis may take place only with reference to the chiller's performance (in terms of COP and free-cooling power output), whereas the base IT electric load is assumed constant throughout the year.

Finally, annual operating costs and $\mathrm{CO}_{2}$ emissions can be calculated as follows:

$$
\begin{aligned}
C & =c_{N G} \frac{E}{\Delta h_{L H V, \mathrm{NG}}} \\
m_{\mathrm{CO}_{2}} & =e_{\mathrm{CO}_{2}, N G} \frac{E}{\Delta h_{L H V, \mathrm{NG}}}
\end{aligned}
$$

\section{Results and discussion}

The results of the calculations described in the previous section are reported in Fig. 5 for a data center located in Rome, in terms of primary energy, operating costs and $\mathrm{CO}_{2}$ emission savings that could be obtained with the proposed CHP plant with reference to the conventional data center energy scenario described in section 2. Table 6 shows the same results in absolute values.

In particular, Fig. 5 shows the contribution of the four energy-saving methods discussed in this paper, i.e., from bottom to top: the conversion of the data center to a direct current architecture (labeled $\mathrm{AC} \rightarrow \mathrm{DC}$ ); the adoption of a high-performance chiller, with particular reference to its free-cooling capabilities (free-cool.); the adoption of an efficient power plant instead of the grid to supply the required electrical power $\left(\mathrm{CHP}_{\mathrm{el}}\right)$; finally, supplying the required thermal energy (section 2.2) by means of heat recovered from the CHP plant 
$\left(\mathrm{CHP}_{\text {th }}\right)$. The results clearly point out that significant energy, economic and environmental benefits can arise from the efficient energy management of a data center.

The direct current architecture and the adoption of free-cooling both contribute to reduce data center's electric power requirement, so that their weight on the overall savings is the same for energy, costs and $\mathrm{CO}_{2}$ emissions.

Furthermore, the particularly high electric efficiency, which can be achieved by the CHP plant thanks to the membrane reformer unit, makes it possible to attain remarkable savings by substituting the electric grid with the CHP plant as the data center's power source, particularly in the case of operating costs, because of the substantial difference between electric energy and natural gas costs, at least in Italy (on an energy basis, the former costs approximately 4.44 $\mathrm{c} \in / \mathrm{MJ}$, while the latter costs $1.18 \mathrm{c} \in / \mathrm{MJ})$.

Finally, the availability of heat recovered from the CHP plant makes for another energy and cost saving opportunity, if an office or residential building is located close to data center's premises (in this case, under the particular assumptions made about the thermal load, and specifically about the office building volume, heat recovery from the CHP plant is always sufficient to meet the required thermal load).

The influence of the electrical energy to natural gas cost ratio is described in Fig. 6. With current cost values, the ratio is approximately 3.76 on an energy basis. The data reported in Fig. 6 have been obtained holding the electrical energy cost constant for different natural gas costs. Obviously, the higher the cost ratio, the larger the cost savings in the CHP scenario; anyway, it must be observed that these savings are substantial for a wide range of cost ratios, and that it is generally possible to assume that electric energy and natural gas cost variations will be more or less interrelated.

The influence of data center geographical localization is finally described in Fig. 7, which reports the results obtained for the reference data center located in Milan (MI), Rome (RM) and Palermo (PA). It can be seen that the colder the place, the better the performance of the CHP plant. Indeed, lower average 
temperatures produce more free-cooling output and higher thermal loads (besides higher chiller efficiencies). Fuel cell performance, on the contrary, is not significantly affected by ambient temperature.

\section{Conclusions}

This paper discussed and analyzed annual energy consumption, operating costs and $\mathrm{CO}_{2}$ emissions related to the operation of a data center with an IT equipment electric power consumption of $100 \mathrm{~kW}$ located in Italy, taking first into account current typical energy efficiency values for this particular type of building, then an advanced data center energy management system based on a direct current architecture, with cooling provided by a state-of-the-art vapor compression chiller equipped with a free-cooling unit, and with the main power supply provided by a CHP plant based on a membrane reformer unit and a PEM fuel cell. The CHP unit also supplies thermal energy to an office building located close to the data center facility.

The simulations have demonstrated that the adoption of advanced energy management technologies can bring about remarkable energy, cost and emission savings in the operation of a data center, in line with results estimated by dedicated studies such as the EPA report on data centers [8]: in particular, annual energy costs can be cut by more than $100 \mathrm{k} €$, representing a $47 \%$ cost reduction, when the thermal energy from the CHP system can be usefully recovered. Such remarkable savings must obviously be weighted against investment costs and durability performance for the membrane reformer and the PEM fuel cell that are currently not yet fully satisfactory. It must be noted, however, that great effort is being put on both these research topics, thanks to the promising results achievable. For example, a demonstration membrane reformer unit has been recently set up and tested [22], obtaining encouraging results in terms of system efficiency, footprint, hydrogen purity and production rate (up to $40 \mathrm{~m}_{\mathrm{n}}^{3} / \mathrm{h}$ ).

The innovative data center energy management system can also offer substantial savings from an environmental point of view, even if less remarkable 
than cost savings due to the electricity to natural gas cost ratio in Italy. The electric to natural gas cost ratio is obviously an important factor in determining the economic results achievable by the CHP system; anyway, even though cost savings decrease with increasing natural gas costs, good results can still be obtained for a wide range of electric to natural gas cost ratios. Therefore, since electricity and natural gas cost fluctuations are obviously not independent on each other, the economic results of a CHP system are not going to be significantly altered by possible future price oscillations.

Finally, due to the influence of ambient temperature on thermal load and on free-cooling power output, the localization of the data center is a significant factor for the CHP plant's performance, with considerably higher energy and cost savings obtained in colder climates. 


\section{Nomenclature}

\begin{tabular}{|c|c|}
\hline$a$ & activity \\
\hline$A$ & area $\left(\mathrm{m}^{2}\right)$ \\
\hline$e$ & specific emissions $\left(\mathrm{kg} / \mathrm{kWh}\right.$ or $\left.\mathrm{kg} / \mathrm{m}_{\mathrm{n}}^{3}\right)$ \\
\hline$E$ & energy, $(\mathrm{J}$ or $\mathrm{Wh})$ or cell potential $(\mathrm{V})$ \\
\hline$F$ & Faraday's constant $\left(96480 \mathrm{C} \mathrm{mol}^{-1}\right)$ \\
\hline$g$ & molar Gibbs' free energy $\left(\mathrm{J} \mathrm{mol}^{-1}\right)$ \\
\hline$h$ & molar enthalpy $\left(\mathrm{J} \mathrm{mol}^{-1}\right)$ \\
\hline$k$ & membrane permeability $\left(\mathrm{mol} \mathrm{s}^{-1} \mathrm{~m}^{-1} \mathrm{~Pa}^{-0.5}\right)$ \\
\hline$i$ & current density $\left(\mathrm{A} \mathrm{cm}^{-2}\right)$ \\
\hline$I$ & current $(\mathrm{A})$ \\
\hline$m$ & mass (kg) or coefficient in Eq. (19) (V) \\
\hline$n$ & coefficient in Eq. (19) $\left(\mathrm{A}^{-1} \mathrm{~cm}^{2}\right)$ \\
\hline$\dot{n}$ & molar flow rate $\left(\mathrm{mols}^{-1}\right)$ \\
\hline$p$ & pressure (bar) \\
\hline$P$ & power $(\mathrm{kW})$ \\
\hline$r$ & fuel cell's area-specific resistance $\left(\Omega \mathrm{cm}^{2}\right)$ \\
\hline$t$ & membrane thickness $(\mathrm{m})$ \\
\hline$T$ & temperature $(\mathrm{K})$ \\
\hline$V$ & voltage $(\mathrm{V})$ or volume $\left(\mathrm{m}^{3}\right)$ \\
\hline$x$ & molar fraction \\
\hline
\end{tabular}

Greek letters

$\alpha$ coefficient in Eq. (19)

$\gamma$ hydrogen recovery factor

$\delta$ heating degree day, $\mathrm{K}$

$\varepsilon$ specific heat load $\left(\mathrm{Wh} \mathrm{m}^{-3} \mathrm{~K}^{-1}\right)$

$\eta \quad$ efficiency

$\sigma \quad$ steam-to-carbon ratio 


$\begin{array}{ll}\text { Superscripts } & \text { and subscripts } \\ a & \text { activation } \\ c e l l & \text { related to a single cell } \\ c v & \text { control volumes } \\ e & \text { electrons } \\ e l & \text { electric } \\ f & \text { feed, formation } \\ m & \text { membrane } \\ p & \text { permeate } \\ r e v & \text { reversible } \\ S R & \text { steam reforming unit } \\ t h & \text { thermal }\end{array}$

Acronyms

AC Alternating Current

CHP Combined Heat and Power

COP Coefficient Of Performance

DC Data Center, Direct Current

DCiE Data Center infrastructure Efficiency

FC Fuel Cell

HVAC Heating, Ventilation and Air Conditioning

IT Information Technology

LHV Lower Heating Value

NG Natural Gas

PDU Power Distribution Unit

PSU Power Supply Unit

UPS Uninterruptible Power Supply 


\section{References}

[1] Koomey JG. Woldwide electricity used in data centers. Environmental Research Letters 2008;3:034008.

[2] Kant K. Data center evolution. Computer Networks 2009;53:2939-2965.

[3] Belady C, Rawson A, Pflueger J, Cader T. The Green Grid data center power efficiency metrics: PUE and DCiE. http: //www.thegreengrid.org/ /media/WhitePapers/White_Paper_6_ __PUE_and_DCiE_Eff_Metrics_30_December_2008.ashx?lang=en; 2007.

[4] Mitchell-Jackson J, Koomey JG, Nordman B, Blazek M. Data center power requirements: measurements from Silicon Valley. Energy 2003:28:837-850.

[5] Karlsson JF, Moshfegh B. Investigation of indoor climate and power usage in a data center. Energy and Buildings 2005;37:1075-1083.

[6] Sun HS, Lee SE. Case study of data centers' energy performance. Energy and Buildings 2006;38:522-533.

[7] Greenberg S, Mills E, Tschudi B, Rumsey P, Myatt B. Best practices for data centers: Lessons learned from benchmarking 22 data centers. In: Proceedings of the 2006 ACEEE Summer Study on Energy Efficiency in Buildings. Pacific Grove, CA (USA); 2006.

[8] U.S. Environmental Protection Agency . EPA report to congress on server and data center efficiency. http://www.energystar.gov/index.cfm?c= prod_development.server_efficiency_study; 2007.

[9] Guizzi GL, Manno M, Zaccagnini A. Comparative analysis of combined cooling, heating and power systems covering data centers energy needs. In: Proceedings of the $22^{\text {nd }}$ International Conference on Efficiency, Cost, Optimization (ECOS 2009). Foz do Iguaçu, Paraná, Brazil; 2009. 
[10] Simmons L. Peer review of Lawrence Berkeley National Laboratory (LBNL) study on direct current in the data center. http://hightech . lbl.gov/dc-powering/pubs/Peer_Review_of_LBNL_Study.pdf; 2008.

[11] Ton M, Fortenbery B, Tschudi W. DC power for improved data center efficiency. http://hightech.lbl.gov/documents/DATA_CENTERS/ DCDemoFinalReport.pdf; 2007.

[12] Silicon Valley Leadership Group. Data center energy forecast. Final report. http://svlg.net/campaigns/datacenter/docs/DCEFR_report. pdf; 2008.

[13] Rasmussen N. Calculating total cooling requirements for data centers. http://www.apcmedia.com/salestools/NRAN-5TE6HE_R2_EN.pdf; 2007.

[14] ENEL. Environmental report (in italian). http://www.enel.it/azienda/ it/investor_relations/bilanci_documenti/doc/2007RAPPAMB/ rapporto_ambientale_2007.pdf; 2007.

[15] Campanari S, Macchi E, Manzolini G. Innovative membrane reformer for hydrogen production applied to pem micro-cogeneration: Simulation model and thermodynamic analysis. International Journal of Hydrogen Energy 2008;33:1361-1373.

[16] Bottino A, Comite A, Capannelli G, Di Felice R, Pinacci P. Steam reforming of methane in equilibrium membrane reactors for integration in power cycles. Catalysis Today 2006;118:214-222.

[17] Li A, Lim CJ, Grace JR. Staged-separation membrane reactor for steam methane reforming. Chemical Engineering Journal 2008;138:452-459.

[18] Lutz AE, Bradshaw RW, Keller OJ, Witmer DE. Thermodynamic analysis of hydrogen production by steam reforming. International Journal of Hydrogen Energy 2003;28:159-167. 
[19] Guizzi GL, Manno M, De Falco M. Hybrid fuel cell-based energy system with metal hydride hydrogen storage for small mobile applications. International Journal of Hydrogen Energy 2009;34:3112-3124.

[20] Larminie J, Dicks A. Fuel Cell Systems Explained (Second Edition). John Wiley \& Sons; $2^{\text {nd }}$ ed.; 2003. ISBN 047084857X.

[21] Lattner JR, Harold MP. Comparison of conventional and membrane reactor fuel processors for hydrocarbon-based PEM fuel cell systems. International Journal of Hydrogen Energy 2004;29:393-417.

[22] Shirasaki Y, Tsuneki T, Ota Y, Yasuda I, Tachibana S, Nakajima $\mathrm{H}$, et al. Development of membrane reformer system for highly efficient hydrogen production from natural gas. International Journal of Hydrogen Energy 2009;34:4482-4487. 


\section{List of Figures}

1 Total electricity use for data centers in the US in 2000 and 2005, including cooling and auxiliary equipment $[1]$. . . . . . . . 25

2 Data center power distribution systems: traditional AC (top) and high-voltage DC (bottom) . . . . . . . . . . . . 26

3 Layout of the cogeneration system . . . . . . . . . . . . . 27

4 Influence of steam-to-carbon ratio on specific membrane area (with reference to $1 \mathrm{mols}^{-1}$ of natural gas input) . . . . . . . . 28

5 Primary energy, operating costs and $\mathrm{CO}_{2}$ emission savings for the reference data center located in Rome . . . . . . . . . . . . 29

6 Influence of electric energy to natural gas cost ratio on operating cost savings . . . . . . . . . . . . . . . . . . 30

7 Primary energy savings for the reference data center located in Milan, Rome or Palermo . . . . . . . . . . . . . . . . . . 31

\section{List of Tables}

1 Estimate of PUE contribution by equipment per scenario used in the EPA Report $[12]$. . . . . . . . . . . . . . . . . . 32

2 Membrane reformer parameters . . . . . . . . . . . 33

$3 \quad$ Stream data for relevant points of the cogeneration system of Fig. 334

4 Empirical coefficients in the analytical expression of the polarization curve, Eq. (19) . . . . . . . . . . . . . . . . 35

5 Simulation assumptions ................ 36

6 Annual results for the reference data center located in Rome . . 37 


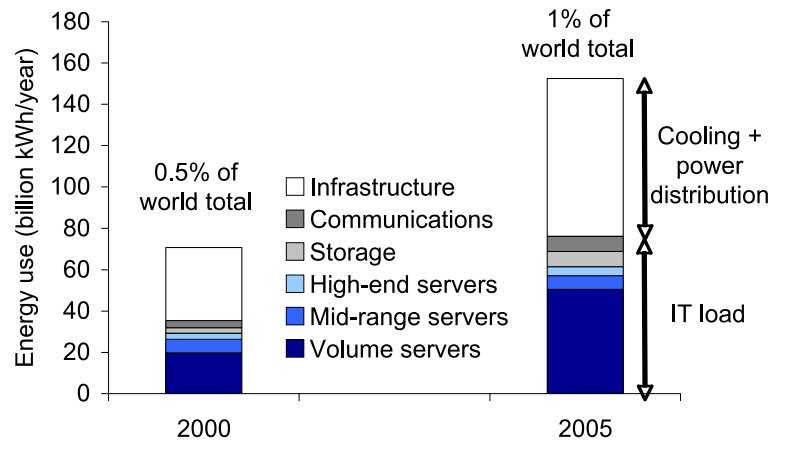

Figure 1: Total electricity use for data centers in the US in 2000 and 2005, including cooling and auxiliary equipment [1] 

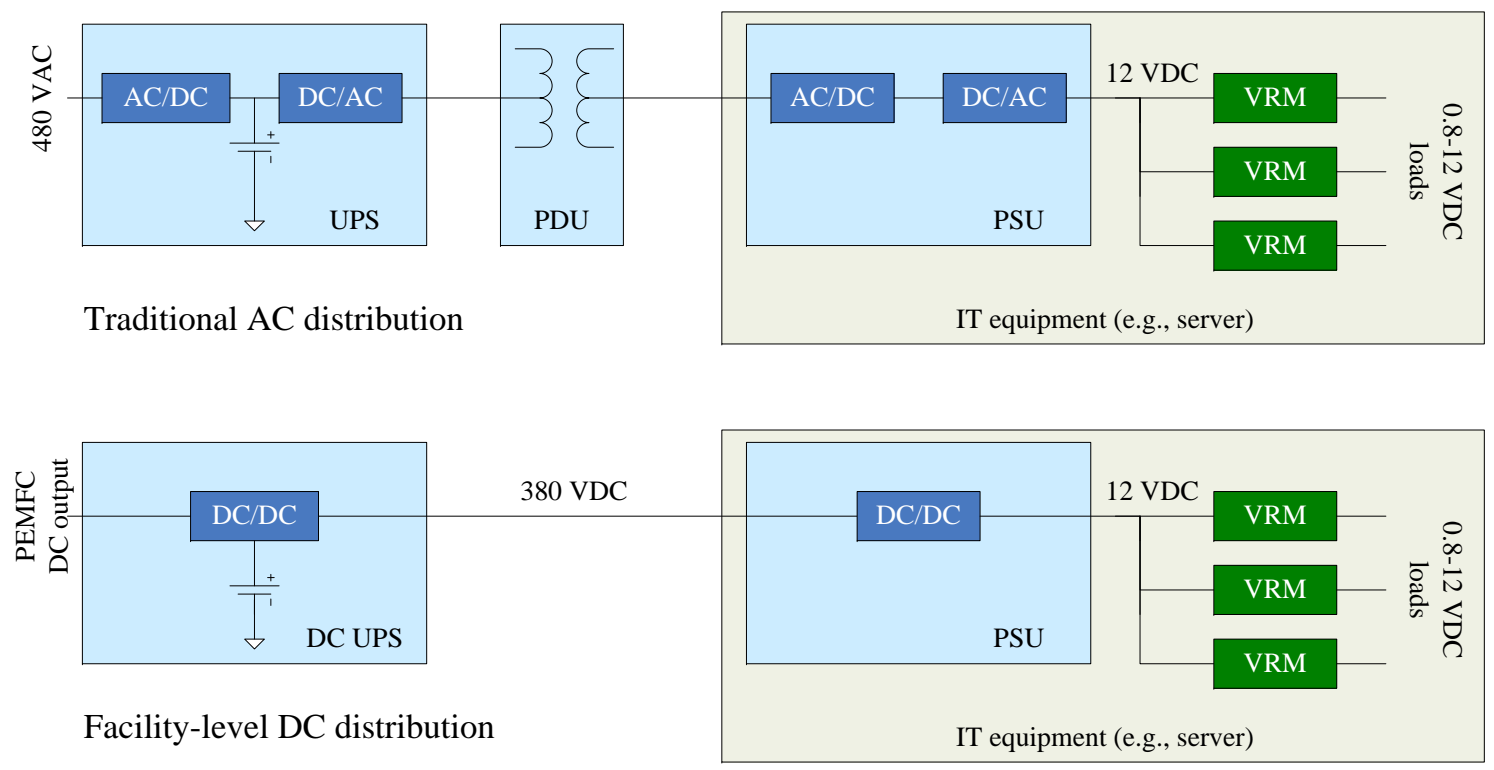

Figure 2: Data center power distribution systems: traditional AC (top) and high-voltage DC (bottom) 


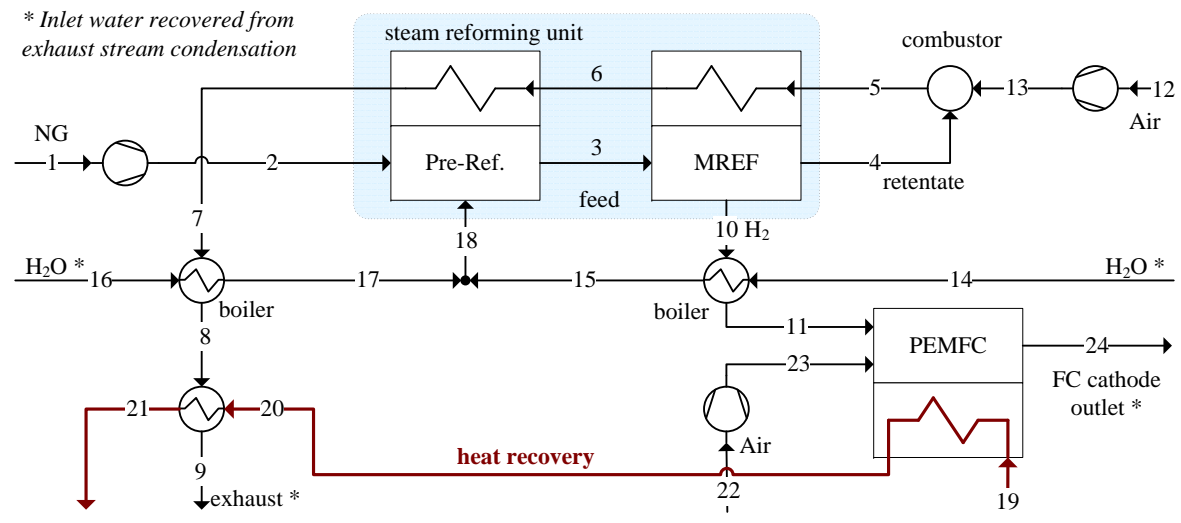

Figure 3: Layout of the cogeneration system 


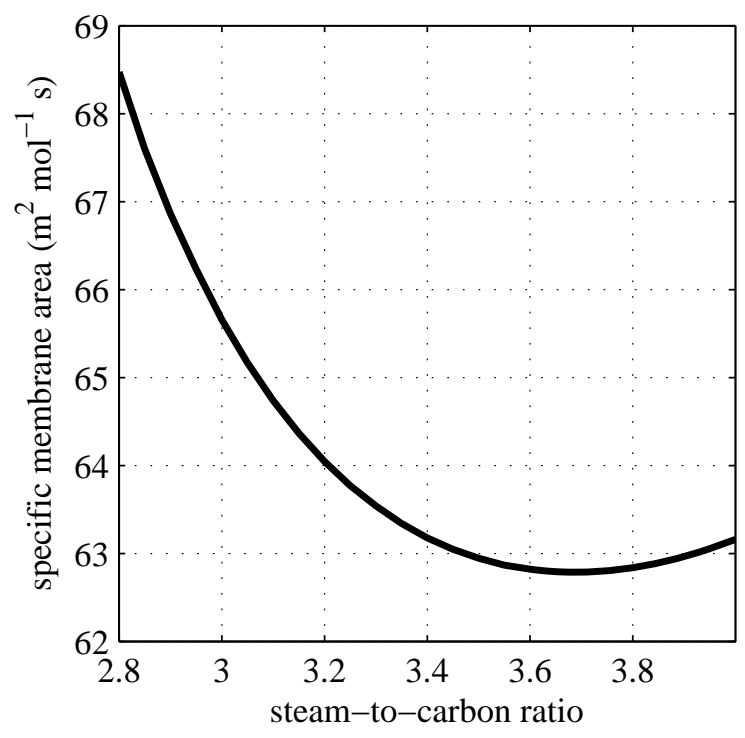

Figure 4: Influence of steam-to-carbon ratio on specific membrane area (with reference to $1 \mathrm{mols}^{-1}$ of natural gas input) 


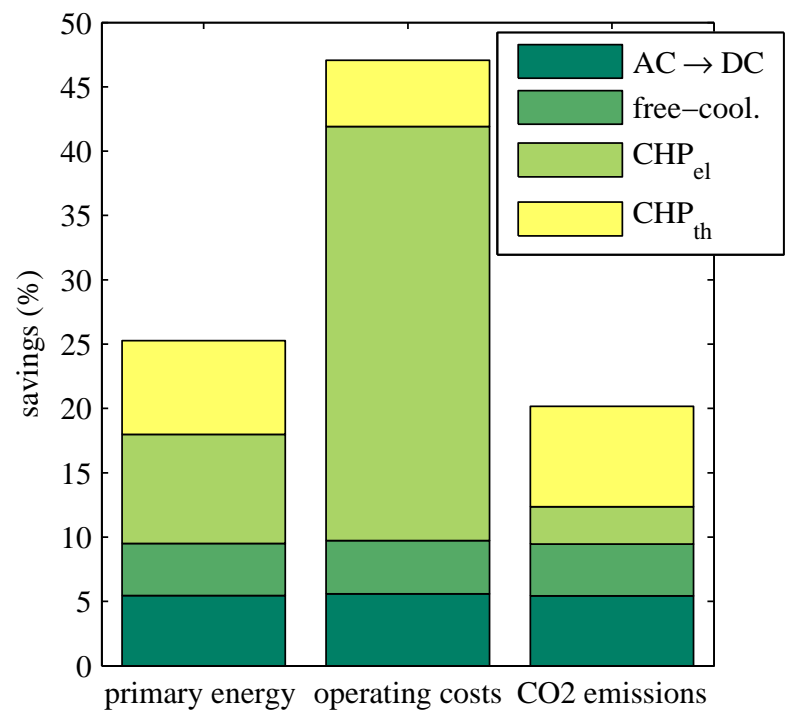

Figure 5: Primary energy, operating costs and $\mathrm{CO}_{2}$ emission savings for the reference data center located in Rome 


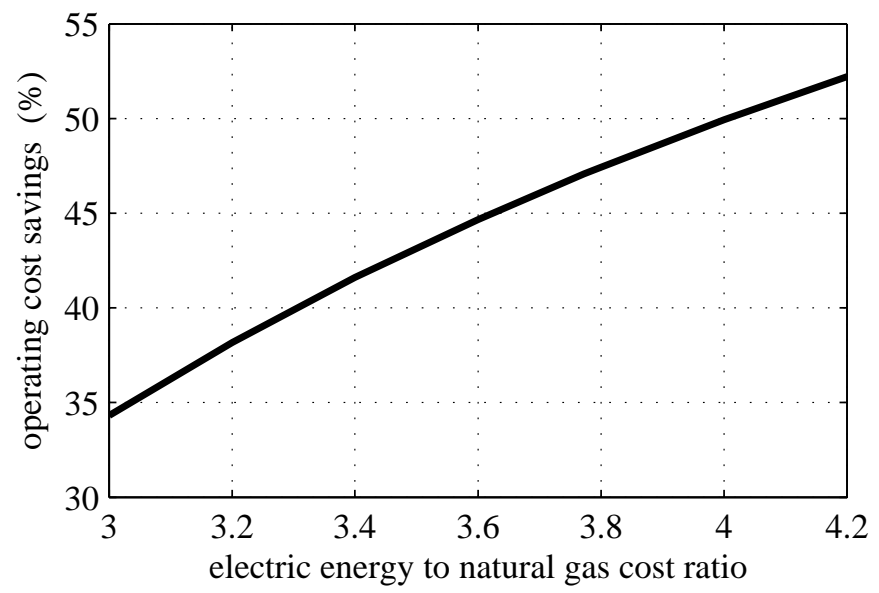

Figure 6: Influence of electric energy to natural gas cost ratio on operating cost savings 


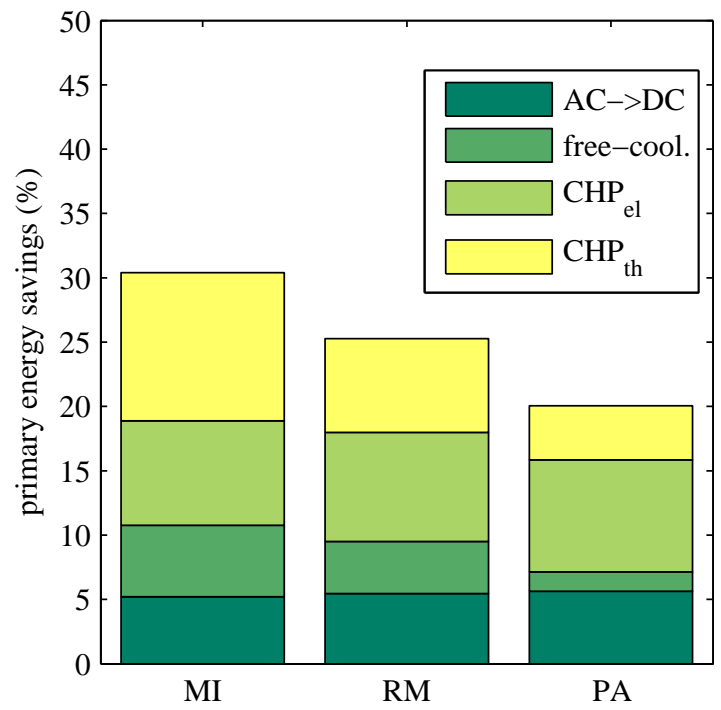

Figure 7: Primary energy savings for the reference data center located in Milan, Rome or Palermo 


\begin{tabular}{llllllll}
\hline & $\begin{array}{l}\text { IT } \\
\text { Equip- } \\
\text { ment }\end{array}$ & $\begin{array}{l}\text { Trans- } \\
\text { former } \\
\text { Losses }\end{array}$ & $\begin{array}{l}\text { UPS } \\
\text { Losses }\end{array}$ & $\begin{array}{l}\text { Chilled } \\
\text { Water }\end{array}$ & Fans & $\begin{array}{l}\text { Light- } \\
\text { ing }\end{array}$ & Total \\
\hline Historical & 1.0 & 0.05 & 0.17 & 0.54 & 0.16 & 0.08 & $\mathbf{2 . 0 0}$ \\
Improved operations & 1.0 & 0.05 & 0.20 & 0.30 & 0.13 & 0.02 & $\mathbf{1 . 7 0}$ \\
Best practice & 1.0 & 0.03 & 0.10 & 0.10 & 0.03 & 0.02 & $\mathbf{1 . 3 0}$ \\
State of art & 1.0 & 0.03 & 0.05 & & 0.04 & 0.02 & $\mathbf{1 . 2 0}$ \\
\hline
\end{tabular}

Table 1: Estimate of PUE contribution by equipment per scenario used in the EPA Report $[12]$ 


\begin{tabular}{ll}
\hline Parameter & Value \\
\hline$t$ & $50 \mu \mathrm{m}$ \\
$k_{0}$ & $1.97 \times 10^{-7} \mathrm{~mol} \mathrm{~s}^{-1} \mathrm{~m}^{-1} \mathrm{~Pa}^{-0.5}[16]$ \\
$E_{a}$ & $13810 \mathrm{~J} \mathrm{~mol}^{-1}[16]$ \\
$\gamma$ & 0.65 \\
$T$ & $600{ }^{\circ} \mathrm{C}$ \\
$p_{f, \text { in }}$ & $9.0 \mathrm{bar}$ \\
$p_{p, \text { out }}$ & $1.3 \mathrm{bar}$ \\
\hline
\end{tabular}

Table 2: Membrane reformer parameters 


\begin{tabular}{|c|c|c|c|c|c|c|c|c|c|c|c|}
\hline \multirow[t]{2}{*}{ Point } & $T$ & $p$ & $n^{*}$ & $m^{*}$ & $\mathrm{CH}_{4}$ & $\mathrm{CO}$ & $\mathrm{CO}_{2}$ & $\mathrm{H}_{2}$ & $\mathrm{H}_{2} \mathrm{O}$ & $\mathrm{O}_{2}$ & $\mathrm{~N}_{2}$ \\
\hline & {$\left[{ }^{\circ} \mathrm{C}\right]$} & [bar] & {$\left[\frac{\mathrm{mol}}{\mathrm{mol}_{\mathrm{NG}}}\right]$} & {$\left[\frac{\mathrm{kg}}{\mathrm{kg}_{\mathrm{NG}}}\right]$} & \multicolumn{7}{|c|}{$\mathrm{mol} \%$} \\
\hline 1 & 25.0 & 1.00 & 1.00 & 1.00 & \multicolumn{7}{|c|}{ see footnote at page 7} \\
\hline 3 & 600.0 & 8.91 & 5.64 & 4.66 & 11.6 & 1.5 & 6.9 & 29.4 & 50.5 & 0.0 & 0.1 \\
\hline 4 & 600.0 & 8.64 & 3.75 & 4.35 & 4.9 & 2.9 & 22.2 & 18.0 & 51.7 & 0.0 & 0.2 \\
\hline 5 & 1386.0 & 1.25 & 8.22 & 11.97 & 0.0 & 0.0 & 13.7 & 0.0 & 38.1 & 2.8 & 45.4 \\
\hline 6 & 1132.7 & 1.22 & 8.22 & 11.97 & 0.0 & 0.0 & 13.7 & 0.0 & 38.1 & 2.8 & 45.4 \\
\hline 7 & 725.3 & 1.21 & 8.22 & 11.97 & 0.0 & 0.0 & 13.7 & 0.0 & 38.1 & 2.8 & 45.4 \\
\hline 8 & 175.4 & 1.19 & 8.22 & 11.97 & 0.0 & 0.0 & 13.7 & 0.0 & 38.1 & 2.8 & 45.4 \\
\hline 9 & 75.0 & 1.16 & 8.22 & 11.97 & 0.0 & 0.0 & 13.7 & 0.0 & 38.1 & 2.8 & 45.4 \\
\hline 10 & 600.0 & 1.33 & 2.83 & 0.31 & 0.0 & 0.0 & 0.0 & 100.0 & 0.0 & 0.0 & 0.0 \\
\hline 11 & 75.0 & 1.30 & 2.83 & 0.31 & 0.0 & 0.0 & 0.0 & 100.0 & 0.0 & 0.0 & 0.0 \\
\hline 12 & 25.0 & 1.00 & 4.86 & 7.62 & 0.0 & 0.0 & 0.0 & 0.0 & 3.0 & 20.3 & 76.6 \\
\hline 14 & 25.0 & 9.18 & 0.78 & 0.77 & 0.0 & 0.0 & 0.0 & 0.0 & 100.0 & 0.0 & 0.0 \\
\hline 16 & 25.0 & 9.18 & 2.92 & 2.89 & 0.0 & 0.0 & 0.0 & 0.0 & 100.0 & 0.0 & 0.0 \\
\hline 18 & 370.0 & 9.00 & 3.70 & 3.66 & 0.0 & 0.0 & 0.0 & 0.0 & 100.0 & 0.0 & 0.0 \\
\hline 19 & 55.0 & 2.08 & 497.11 & 492.07 & 0.0 & 0.0 & 0.0 & 0.0 & 100.0 & 0.0 & 0.0 \\
\hline 20 & 65.8 & 2.04 & 497.11 & 492.07 & 0.0 & 0.0 & 0.0 & 0.0 & 100.0 & 0.0 & 0.0 \\
\hline 21 & 70.0 & 2.00 & 497.11 & 492.07 & 0.0 & 0.0 & 0.0 & 0.0 & 100.0 & 0.0 & 0.0 \\
\hline 22 & 25.0 & 1.00 & 8.33 & 13.06 & 0.0 & 0.0 & 0.0 & 0.0 & 3.0 & 20.3 & 76.6 \\
\hline 24 & 70.0 & 1.30 & 9.75 & 13.38 & 0.0 & 0.0 & 0.0 & 0.0 & 31.6 & 2.9 & 65.5 \\
\hline
\end{tabular}

Table 3: Stream data for relevant points of the cogeneration system of Fig. 3 


\begin{tabular}{ll}
\hline Coefficient & Value \\
\hline$\alpha$ & 0.3629 \\
$i_{0}$ & $6.257 \times 10^{-6} \mathrm{~A} \mathrm{~cm}^{-2}$ \\
$r$ & $0.1752 \Omega \mathrm{cm}^{2}$ \\
$m$ & $1.879 \times 10^{-4} \mathrm{~V}$ \\
$n$ & $6.887 \mathrm{~A}^{-1} \mathrm{~cm}^{2}$ \\
\hline
\end{tabular}

Table 4: Empirical coefficients in the analytical expression of the polarization curve, Eq. (19) 


\begin{tabular}{ll}
\hline Parameter & Value \\
\hline DC/DC converter efficiency & $97.5 \%[19]$ \\
FC auxiliary consumption & $1.5 \%$ \\
compressor polytropic efficiency & 0.70 \\
reformer pressure loss & $4 \%$ \\
heat exchangers pressure loss & $2 \%$ \\
combustor pressure loss & $4 \%$ \\
minimum $\Delta T$ pinch-point for boilers & $10{ }^{\circ} \mathrm{C}$ \\
\hline
\end{tabular}

Table 5: Simulation assumptions 


\begin{tabular}{lccc}
\hline & Conventional & CHP & CHP savings \\
\hline Primary energy consumption / GWh & 4.196 & 3.136 & 1.061 \\
Operating costs / $\mathrm{k} \in$ & 252.1 & 133.0 & 118.3 \\
$\mathrm{CO}_{2}$ emissions / t & 801.1 & 639.6 & 161.5 \\
\hline
\end{tabular}

Table 6: Annual results for the reference data center located in Rome 